\title{
Efficiency Analysis on Traditional Market in Salatiga, An Application of Data Envelopment Analysis
}

\author{
Lintangsari Susanto Putri* and Evi Gravitiani \\ Economic and Business Faculty, Universitas Sebelas Maret \\ *Email: lintangsari92@gmail.com
}

\begin{tabular}{|l|}
\hline \multicolumn{1}{|c|}{ Published: $30 / 09 / 2021$} \\
\hline $\begin{array}{l}\text { How to cite (in APA style): } \\
\text { Putri, L, S., Gravitiani, E. (2021). Efficiency Analysis on Traditional Market in Salatiga, An Application of Data Envelop- } \\
\text { ment Analysis. Jurnal Ekonomi dan Bisnis Jagaditha, 8(2), 146-156. doi: https://doi.org/10.22225/jj.8.2.2021.146-156 }\end{array}$ \\
\hline
\end{tabular}

\begin{abstract}
The traditional markets in Salatiga City are managed by the Unit Pelaksana Teknis Dinas (UPTD) Dinas Perdagangan. UPTD Dinas Perdagangan policy in Salatiga City is free rental fees for 3 years for newly built traditional markets. The objective of this study was to analyze the comparison of the level of efficiency of market management at the UPTD Dinas Perdagangan. The data used in this research are primary and secondary data obtained from the UPTD and Dinas Perdagangan Salatiga City. The method used in this study was a quantitative research method with the tools used is the Data Envelopment Analysis model of the Charnes, Cooper, dan Rhodes (CCR) dan Banker, Charnes, dan Cooper (BCC). The variable that is regulated in the research is the efficiency value of the UPTD Class A and B Dinas Perdagangan. The independent variables in the study included 2 variables, namely the input and output variables. Based on the analysis, the results of this study reveal that the two UPTDs have a balanced efficiency in their management and both UPTD Class A and Class B still make the development of traditional markets become in harmony with each other. In addition, market revitalization managed by UPTD for Class A and ClassB has been developing. The research suggestion is to maintain the results that have been achieved by the two UPTD Dinas Perdagangan. Both UPTDs have had innovations in managing traditional markets that have included the appropriate target market environment.
\end{abstract}

Keywords: BCC; CCR; data envelopment analysis (DEA), UPTD pasar tradisional

\section{INTRODUCTION}

The concept of local wisdom can be seen in traditional markets. Traditional markets in the region help the economic wheel run so that it increases in line with the increasing number of life needs that result in the slow development of the market (Sitohang, Marpaung, \& Lubis, 2020). Traditional markets are one of the economic wheels for businesses. Major \& Tannous (2020) say the traditional market is a pedestrian market that is accessible to the public including buildings that have alleys, plazas and many shops. The market is a gathering place for people to do buying and selling activities, and socializing. The market is also called a closed area outside or indoors that is permanent or temporary.

Defense of a concept of local wisdom in traditional markets can be done with a revitalization program. Ren et al. (2014:32-38) describe revitalization as an outdated rebuilding program that fails to meet the needs of contemporary users or potential users. Revitalization is one of the government's steps in maintaining the existence of traditional markets in the current era.

Revitalization has the goal of fixing weaknesses in traditional markets so that visitors to traditional markets can increase. At the heart of the revitalization program is a series of integrated and comprehensive actions designed to solve problems, promote sustainability, and improve regional development competitiveness (Kiss, 2007). The application of revitalization in Indonesia refers to law on trade no. 7 of 2014. The Ministry of Trade argues that the concept of revitalization of traditional markets is a physical and nonphysical reform of market 
management and integration with other sectors.

Opinions on the weakness of traditional markets were expressed by Cadillah (2011) and approved by Ferricha \& Fauzan (2020:9), Traditional Market has the impression of muddy, dirty, smelly and has an overly congested environment for buyers and sellers to transact. Physical revitalization must be accompanied by non-physical revitalization including economic, management and social revitalization. Economic revitalization is a redevelopment to increase income and accommodation of economic activities informally and formally on traditional markets. Revitalization of management is a redevelopment that focuses on the process of placing market traders, financing/capital revitalization programs, and operational standards of market service procedures. Sociocultural revitalization is the rebuilding of the market environment that can improve the dynamics and social life of the community.

Exploration of economic and social attitudes in revitalization programs has a perception of sustainability and influence on community involvement in traditional markets. The partnership between the people and the government is effective because it allows the people involved to take control of the process. Variable economic activities and social activities have a positive influence in supporting environmental aspects. Both variables of economic activity are more dominant in influencing environmental aspects than social activities (Wahyudi et al., 2019).

Data from Badan Pusat Statistik Jawa Tengah (2019) shows that Jawa Tengah has a market number of 1,482 units and is ranked as the second largest market in Indonesia. One of the implementations of the traditional market revitalization program in Jawa Tengah is in the traditional market of Salatiga City. Salatiga is one of the cities in Jawa Tengah Province that is rebuilding traditional markets. The application of revitalization is to advance the increase of trading centers through revitalization with the aim of generating the interest of traders and buyers to transact back in traditional markets. Unit Pelaksana Teknis Dinas (UPTD) policy is free of rent for 3 years for newly built market. This is considered to increase traders' interest in using the region and create a new market environment.

The Market Management Agency in Salatiga is divided into 2 UPTD. UPTD is an operational technical implementing element to carry out some of the tasks of the Regional
Device Organization (OPD) as well as provide services to the community in the field of market management. Good market management has the aim of increasing Regional Native Income (PAD) and maintaining market comfort and order.

After the revitalization process of Traditional Market in Salatiga City the competition between modern market and traditional market can still be seen. Traditional markets are only beginning to emerge, but the interest of traders to sell in the market has not increased. The government took steps to increase the number of traders in the market by freeing up the use of market stalls for 3 years. Management is the responsibility of market managers and market users. The achievement target of each different market makes the efficiency of UPTD management need to be analyzed to know the level of efficiency of market management in each UPTD in Salatiga using DEA analysis.

Market management refers to the duties and functions of the device in accordance with The Mayor of Salatiga City Regulation number 12 of 2018 concerning the establishment of UPTD Dinas Perdagangan. Market management in Salatiga is carried out by UPTD, namely UPTD A and UPTD B.

Some previous related studies have been conducted about DEA analysis is used to analyze the efficiency of the performance of a company or factory. Widiyana \& Indiyanto (2017) argue that DEA research can help measure the level of efficiency so that the five branches of the Heaven Store which are the object of research can improve service quality after knowing the comparison of the efficiency and inefficient results of the five branches. Murbarani (2018) argues that traditional markets that have been revitalized have both efficiency and inefficiency results in the DEA analysis. Research on traditional markets in Surakarta proves that there are 24 traditional markets analyzed. The 24 traditional markets resulted in 9 efficient markets and 15 inefficient markets. Fatimah \& Mahmudah (2017) explain the DEA analysis on the object of research 103 elementary schools in Jakarta. The results of the analysis prove that only 14 elementary schools have efficiency scores, while the other 89 elementary schools have inefficiency scores. Niswati (2014) argues that the DEA analysis on the branch company of PT. XYZ has a three-pronged efficiency result and two branches has a lower-efficiency value, which is below one $(<1)$.

The description of the background and the 
previous studies above, it is known that efficiency analysis using the DEA method needs to be carried out to determine the achievement targets of each market. The level of achievement of different traditional markets makes the efficiency of traditional markets in Salatiga City need to be analyzed to determine the efficiency level of traditional market management in Salatiga City. Therefore, this study aims to analyze the efficiency level of market management in both UPTD, with Data Envelopment Analysis Method.

\section{CONCEPTUAL FRAMEWORK}

\section{Theory of Demand and Supply}

Sepulveda (2020) argues demand and supply are lowered separately with a simple three-step procedure. The request has a costbenefit rule used to get the maximum price willing buyers are willing to pay (WTP) for different units; then the units are sorted from highest to lowest WTP, and the quantity is obtained simply by calculating units with WTP not lower than the specified price. Captors have a cost-benefit rule that is used to obtain a minimum price that willing sellers willing to charge (WTC) for different units; then the units are sorted from lowest to highest WTC, and the quantity offered is obtained by calculating units with WTC no higher than a certain price. This context refers to the law of demand (supply) simply stated as the inverse (direct) relationship between the price of the goods and the number of transactions that pass the cost-benefit rule for the buyer (seller).

Caginalp \& Caginalp (2019) argues the similarity of price dynamics in which supply and demand have a symmetrical role. The equation applies to ordinary goods and assets having such properties can help forecast the market up or down. The cause of the maximum supply and demand imbalance in practice is the behavioral effect, especially in the market. Behavioral effects can be incorporated into the model when these factors are established.

\section{Theory of Traditional Market}

Putra \& Rudito (2015) explained that the growing buying and selling activities encourage human behavior to create trading instruments. The instrument of such trade is the market. The narrower geographical scope is the traditional market in Indonesia. Putra and Rudito believe the traditional market is one of the comprehensive factors of the nation's economic wheels. Traditional markets that have been feared for years are likely to die in the near future. The Government of Indonesia prevents the elimination of traditional markets by applying the concept of revitalization of traditional markets.

Major \& Tannous (2020) argues The Traditional Market is also called Souq in Arabic and Socco in Spanish terms is a publicly accessible pedestrian market with arcades, plazas, and many shops where people gather regularly to buy and sell goods, socialize, and walk. The market area is divided into retail located on the street, while other traders are on the inside and outside of the market building.

Sitohang et al. (2020) argues that the market is a forum for trading activities that are inseparable from daily human activities. The rapid development of the population, the greater the demand for the existence of the market both in quantity and quality. A simple definition of the market is the place where the trade transaction is conducted by the seller and the buyer at a certain place and time. The main element in the market sense is the presence of sellers, buyers, places, times, and agreements in dealing. Such a market is also called Traditional Market. The market has a very close relationship with the activities or economic activities of the community in which production, distribution or consumption. The market can be interpreted as an arena of distribution or exchange of goods, in which the interests of producers and consumers meet and in turn determine the continuity of economic activities of the community. The fundamental difference between traditional and modern markets lies in the process of bargaining prices in traditional markets, whereas in modern markets prices are definitely characterized by a price tag. The bargaining process always creates a personal and emotional closeness between sellers and buyers that is impossible to obtain when shopping in modern markets (Sitohang et al., 2020).

The Department of Cooperatives and Small and Medium Enterprises defines the traditional market as a market with a relatively simple form of building, with a relatively unpleasant atmosphere (cramped business space, inadequate parking facilities, poorly maintained market cleanliness, and poor lighting). Goods traded are goods of daily necessities with the quality of goods that are not noticed. The price of goods is relatively cheap, and how to buy them with a bargaining system. Most traders are economically weak and less professional ways of trading. 


\begin{abstract}
Theory of Revitalization
Giantari et al. (2018) argues the revitalization of traditional markets is a government program through the Ministry of Trade and the Ministry of State Cooperatives and Small Businesses that has the aim of empowering micro-businesses that grow in the market with unfit, healthy, clean business transaction facilities that are comfortable as well as facilities owned and managed by traders themselves in cooperative businesses. Revitalization is a re-concept of building systems, both internally and externally. The main focus of revitalization is on conceptualizing system buildings. Revitalization is carried out to integrate the market with the external and internal scope in
\end{abstract} the market.

Ren et al. (2014) the revitalization program has the goal of rebuilding outdated buildings and failing to meet the contemporary needs of users or potential users. The application of revitalization has been an important task in urban regeneration over the past few decades. The discourse and practice of revitalizing industrial sites varies in different places, the essence of revitalization lies in a series of integrated and comprehensive actions designed to solve regional development problems, promote sustainable regional development and improve regional competitiveness (Dixon, 2007).

Kiss (2007) argues it is necessary to introduce different revitalization strategies to suit local circumstances, and monitoring of revitalization outcomes has become a key area of urban study. Evaluation of project revitalization and industrial space policy from various perspectives is including urban competitiveness. The old industrial estate does not have to be physically "old" but is a land and industrial utilization area that fails to meet the needs of regional development and economic performance. The ultimate goal of the revitalization program is economic growth in a region. The transformation and improvement of the old industrial estate involves 3 aspects as follows:

Physical renovation or transformation (refurbish, reconstruction) of the early industrial space.

Economic rebuilding (e.g. industrial improvement, introduction of new functions).

Social change behind the revitalization of the old industrial space there is competition and social change of different forces, e.g. changes in demographic structure, relationships between stakeholders, and their opinions and acquired interests (Pan \& Song, 2017).

\section{Efficiency Theory}

Broekel et al. (2018) argues the term efficiency is used to highlight that the innovation output is compared to the maximum output jumal that can be achieved from the available inputs. Other variables beyond input and output serve as benchmarks in determining the maximum achievable results.

Milliken et al. (2011) argue efficiency using primary data number of visits and variable output and input as an intermediate output measure to measure service quality into a measure of efficiency. Efficiency analysis must have multiproductive properties, i.e. the movement of various types of commodities requires the use of productive resources in quite different ways (Castelló Taliani et al., 2017; Martinez-Budria et al., 1999) .

Lampe \& Hilgers (2015) argues DMU inefficiencies are determined by measuring their distance in the DMU line indicating potential efficiency improvements. The DMU front line shows a wide range of maximum outputs with different input combinations. A minimal combination of inputs is required for mixed output results from DMU below. The frontline of DMU as a result is inefficient and DMU at the border is considered efficient.

\section{Data Envelopment Analysis (DEA)}

Lampe \& Hilgers (2015) DEA analysis is an efficiency measurement method that uses non-parametric models that do not require explicit a priori determination of the relationship between input and output, or rigid importance setting weights for various factors so that functions in research do not need to be defined. DEA analysis is an efficiency evaluation model based on mathematical programming theory. The DEA offers a classic statistical alternative to extracting information from sample observations. The difference between DEA and other parametric approaches is that the DEA optimizes each individual's observations with the aim of calculating separate wise limits determined by the set of appropriate decision management units or Decision Making Units (DMU). The DEA's focal point is on individual observations and not a single optimization statistical approach that focuses on average parameters. DEA refers to each port as DMU, in the sense that each is responsible for converting inputs into output. DEA analysis can involve multiple 
inputs as well as multiple outputs in its efficiency assessment (Abbott \& Doucouliagos, 2004; Lampe \& Hilgers (2015).

Nandy \& Singh (2020) argue the DEA is a linear programming method that aims to calculate efficiency levels. Efficiency level calculation involves inefficient DMU against efficient DMU. Efficient DMU is a temporary value located in the middle of another DMU value below the border. The results of DMU input and output values in dea are as follows:

DEA inputs have a value of reducing input levels by maintaining a constant output level.

Dea output has a value that changes by maintaining input level constants.

The Concept in writing this research begins with buying and selling transactions that occur in traditional markets in the city of Salatiga. Transactions that occur in traditional markets have decreased due to the bad image of the traditional markets each year. The Salatiga city government then implemented a revitalization program and new market development according to the government's recommendation according to Law number 7 of 2014 concerning Trade. Market management in Salatiga is divided into 4 UPTDs, but since 2018 the market management of Salatiga City has been divided into 2 UPTDs, namely UPTD Class A and UPTD Class B. This research will analyze the comparison of the efficiency levels of the two UPTDs of market management in the city of Salatiga. The analysis used the DEA model with input and output variables regarding market management at 2 UPTDs. The result of this research is a comparison of the level of efficiency of the two UPTDs after the revitalization of the Salatiga City Traditional Market.

\section{METHOD}

The types and sources of data in this study are primary data and secondary data. The data required in this study are: UPTD Dinas Perdagangan of Salatiga City is divided into 2 UPTD: a) UPTD Class A consists of Raya I market, Eks Hasil market, Ayam dan Ikan market, Pagi market, Raya II market, Tamansari market, Shoping Centre market, Blauran I market, and blauran II market. b) UPTD Kelas B consists of Sayangan market, Jetis market, Banyu Putih market, Andong market, Rejosari market, Cengek market, and Krenceng market. Primary data obtained from UPTD are: 1) Profile of UPTD Class A and
UPTD Class B of Salatiga City; 2) Number of market managers in UPTD; 3) Total revenue UPTD class A and UPTD class B; 4) Total capacity of Salatiga traditional market; 5) Total traders who rent at Salatiga traditional market; 5) Total traders who occupy kiosks $>3$ years. Meanwhile, secondary Data obtained from Dinas Perdagangan are: 1) Total traditional market of Salatiga city; 2) Number of UPTD managers of Salatiga city market; 3 ) Cost of management of UPTD; 4) Total cost incurred by UPTD to hire employees; 5) Overtime labor costs UPTD.

This research was conducted directly in data collection in Salatiga City by conducting interviews to managers in class A UPTD and class B UPTD. Furthermore, data analysis is done quantitatively by technique Data Envelopment Analysis (DEA). Quantitative method involves the process of collecting, analyzing, interpreting, and writing the results of a study. Specific methods exist in surveys and experimental research related to identifying samples and populations, determining the type of design, collecting and analyzing data, presenting results, making interpretations, and writing research consistently with surveys or experimental studies. Creswell (2003:36) DEA is a tool to evaluate and improve the performance of a business of goods or services.

\section{Variable Analysis}

Dea research object is used in UPTD in Salatiga City. The variable tied to the research is the level of efficiency in the Traditional Market UPTD in Salatiga City. Free variables in the study include:

Input variable.

Number of market managers in UPTD.

Total revenue UPTD.

Wages /salaries are the total costs incurred by UPTD to hire employees.

Overtime fee is the cost of salary for additional workload provided.

Output Variables

The remaining income is the cost earned in one month.

Market Share, is the ability to serve market users.

The number of traders is a market trader who rents a place in a traditional market.

Fixed traders, is the number of traders who occupy kiosks that have been more than 3 years. 


\section{DEA model CRS and VRS}

The DEA approach is used to separate pure technical efficiency from scale efficiency by applying two analyses. Constant Return to Scale (CRS) is a confounding scale and technical effect of efficiency. CRS is a measure of maximum efficiency of weighted outputs and inputs and has the same lower limit value on each DMU resulting in a constant comparison of values. A Variable Return to Scale (VRS) score is pure technical efficiency. VRS has input and output values that do not operate the same so inputs will provide an increase or decrease in output. Both approaches are used to determine practices that operate differently at increasing/reducing the scale limit of results and can establish changes to the efficiency rating model after the scale effect is taken into account so that it can be concluded if the DEA approach is taken into account for efficiency scale measurement (Milliken et al., 2011).

$$
\begin{aligned}
& \underline{\text { DEA Formula }} \\
& \quad h_{s}=\sum_{i=1}^{m} u_{i s} y_{i s} / \sum_{j=1}^{n} v_{j s} x_{j s}
\end{aligned}
$$

$h_{s}=$ efficiency techniques of UPTDs

$u_{i s}=$ output weight value $i$ of UPTDs

$y_{i s}=$ number of outputs i from UPTDs

$v_{j s}=\mathrm{J}$ input weight value of UPTDs

$x_{j s}=$ the number of $\mathrm{j}$ inputs, generated by the

UPTDs, is calculated from $\mathrm{j}=1$ to $n$.

The following is a measure of maximized transformation linear performance:

Maximization

$$
h_{s}=\sum_{i=1}^{m} u_{i} y_{i s}
$$

Constraints

$$
\sum_{i=1}^{m} u_{i} y_{i r}-\sum_{j=1}^{n} v_{j} x_{j r} \leq 0, r=1,2, \ldots \ldots, N
$$

$$
\sum_{j=1}^{n} v_{j} x_{j s}=1 \text { dan } u_{i} \text { dan } v_{j} \geq 0
$$

VRS

Maximization

$$
h_{s}=\sum_{i=1}^{m} u_{i} y_{i r}+U_{0}
$$

Constraints

$$
\sum_{i=1}^{m} u_{i} y_{i r}-\sum_{j=1}^{n} v_{j} x_{j r} \leq 0, r=1,2, \ldots, N
$$

$$
\sum_{j=1}^{n} v_{j} x_{j s}=1 \text { dan } u_{i} \text { dan } v_{j} \geq 0
$$

$\mathrm{U}_{0}$ merupakan potongan yang dapat bernilai positif dan negatif.

\section{Tahap Analisis DEA on Excel Solver}

Ray and Chen (2015) argue a number of altenative data from performance can explain in detail a non-parametric approach that can be applied to a variety of situations and is especially useful when input and output pricing data is not available. The DEA's nonparametric methods were introduced by Charnes, Cooper, and Rhodes (CCR) in 1978 and subsequently generalized by Banker, Charnes, and Cooper (BCC) in 1984.

The stages of DEA using Excel solver

Excel Solver is used to measure the efficiency of all input and output units in a sample at once.

Visual Basic for Application (VBA) Macro to measure the cost efficiency of a factory/ company.

The use of the DEA Fee model applies data to the UPTD Dinas Perdagangan of Salatiga City. This data set includes two observation objects: input and output.

Analysis using four outputs and five inputs. The DEA model can be expressed as follows:

At the beginning we will choose will use the CCR or BCC stage with Orientation to output.

Import data into Excel Spreadsheet Solver with column A steps noting the specified Decision Making Unit (DMU) name, columns $\mathrm{B}$ through $\mathrm{J}$ record showing the original data for output and input.

VBA Macro will direct to do save against data analysis which will appear after click "OK". The results of the data analysis will appear after doing "save".

The next step is to type "exit" then the data analysis results will be divided into 9 sheets. The 9 sheets have summarized dea analysis so as to facilitate research such as slack, summary, score, weight, weightdata, rank, projection, and graph.

\section{RESULT AND DISCUSSION}

Simplification is carried out at the UPTD Dinas Perdagangan which amounts from 4 to 2 UPTD, namely UPTD A and UPTD B. Simplification is also contained in Walikota Salatiga regulation no. 12 year 2018 (Pemerintah Kota salatiga, 2018). The reduction in the number of UPTD from 4 to 2 is assessed by the management of UPTD due to workload rules can only be made 2 UPTD in addition to having the purpose of efficiency 
and facilitate coordination.

The authority of UPTD is as follows:

Submit complaints or information from market traders to Dinas Perdagangan Salatiga city related to market maintenance.

Conduct surveys and repair schedules.

Convey information from the government to be conveyed to market traders.

Channeling market levy costs to Dinas Perdagangan.

Conducting regulations to maintain the safety, comfort, and cleanliness of the Market.

The number of employees of UPTD A and UPTD $B$ has a different number. Employees at UPTD A numbered 74 people and employees at UPTD B numbered 22 people. The second challenge of UPTD has the following differences. The challenges of market management in Salatiga:

\section{UPTD A}

Management of the cleanliness of the market environment.

Arrangement of Street Vendors that cannot be arranged.

Structuring the parking area to reduce congestion.

Control of sidewalk traders.

Lack of order of traders related to the ownership of kiosks, stall, shophouses.

\section{UPTD B}

Advancing public interest to revive the market.

Provide security and cleanliness to the market environment. Embodiment with the presence of security officers and janitors. Security officers who always guard the market 24 hours and janitors to always clean the garbage in the market environment.

Provide convenience to traders by improving inadequate market facilities.

Dealing with thugs in the market environment, related to illegal levies.

Structuring traders who do not obey the rules is prohibited from selling on sidewalks and shoulders of the road.

Making traders have the soul of tolerance of fellow traders.

Creating an orderly environment for each trader by taking care of his own environment and disposing of waste in the provided places.

DEA analysis using Excel DEA- Solver version 8 with CCR model - output and BCC output. The following are the results of input and output data that have been obtained (Table 4.1). The level of efficiency obtained from the input and output values that have been collected, processed to be able to know the efficiency value of the performance of two UPTD in the economy and compare the performance to be known the best level of efficiency that has been achieved by two UPTD. Input data includes internal from UPTD regarding costs while output data is obtained from UPTD range in processing each traditional market.

Table 1. Input and Output Data Results

\begin{tabular}{ccc}
\hline UPTD Kota Salatiga & UPTD A & UPTD B \\
\hline (O) Residual Income & Rp89.624.000 & Rp22.406.000 \\
(O) Market Capacity & 3079 & 568 \\
(O) Number of Mer- & 2023 & 634 \\
chants & 2023 & 276 \\
(O) Merchant 3 years & 74 & 22 \\
(I) Number of Employee & $\mathrm{Rp} 101.624 .000$ & $\mathrm{Rp} 25.406 .000$ \\
(I) Income & $\mathrm{Rp} 12.000 .000$ & $\mathrm{Rp} 3.000 .000$ \\
(I) Management Fee & $\mathrm{Rp} 196.493 .680$ & $\mathrm{Rp} 49.123 .420$ \\
(I) Employee Salary & $\mathrm{Rp} 37.244 .800$ & $\mathrm{Rp} 9.311 .200$ \\
(I) Overtime Fee & &
\end{tabular}




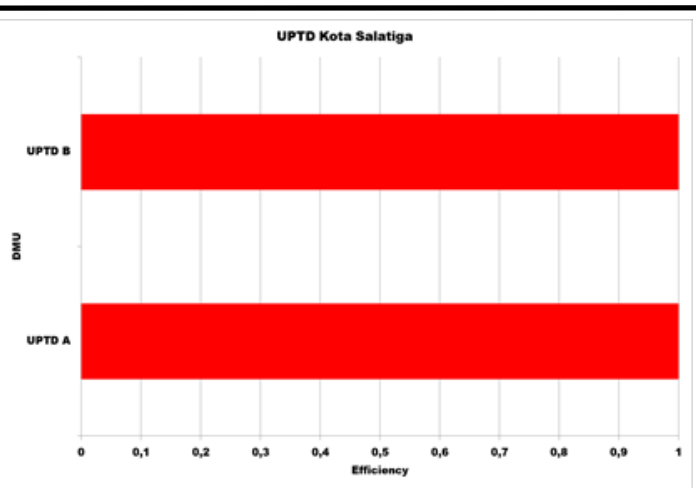

Image 2. UPTD Efficiency Score Graph of Dinas Perdagangan Salatiga City

The picture above explains that the 2 UPTDs used as research objects have a value of $=1$ (efficient). UPTD A and B are DMU from efficiency analysis research using DEA. The study used envelopment data analysis with two models namely CCR and BCC that have output orientation. Discussion of the results of data processing analysis shows if the data analysis results show the efficiency value of both UPTD is 1 . The results of the analysis in table 1 are known if the data has 5 input variables and 4 output variables.

Table 2. BCC-O model efficiency score

\begin{tabular}{cccc}
\hline No. & DMU & Score & $\begin{array}{c}\text { RTS of } \\
\text { Projected } \\
\text { DMU }\end{array}$ \\
\hline 1 & UPTD A & 1 & Constant \\
2 & UPTD B & 1 & Constant \\
\hline
\end{tabular}

Table 3. Statistics analysis of input and output data DEA models CCR and BCC

\begin{tabular}{lrrrr}
\hline & \multicolumn{1}{l}{ Max } & \multicolumn{1}{c}{ Min } & Average & SD \\
\hline Employees & 74 & 22 & 48 & 26 \\
Income & 101.624 .000 & 25.406 .000 & 63.515 .000 & 38.109 .000 \\
outcome & 12.000 .000 & 3.000 .000 & 7.500 .000 & 4.500 .000 \\
Employees Salary & 196.493 .680 & 49.123 .420 & 122.808 .550 & 73.685 .130 \\
Overtime cost & 37.244 .800 & 9.311 .200 & 23.278 .000 & 13.966 .800 \\
profit & 89.624 .000 & 22.406 .000 & 56.015 .000 & 33.609 .000 \\
Market Capacity & $3.079,0$ & 568,0 & $1.823,5$ & $1.255,5$ \\
Traders & $2.023,0$ & 634,0 & $1.328,5$ & 694,5 \\
Traders > 3 years & $2.023,0$ & 276,0 & $1.149,5$ & 873,5 \\
\hline
\end{tabular}

Table 4. Correlation of input and output data of DEA models CCR and BCC

\begin{tabular}{|l|c|c|c|c|c|c|c|c|c|}
\hline $\begin{array}{l}\text { Total/ } \\
\text { Biaya }\end{array}$ & $\mathrm{a}^{1}$ & $\mathrm{~b}$ & $\mathrm{c}$ & $\mathrm{d}$ & $\mathrm{e}$ & $\mathrm{f}$ & $\mathrm{g}$ & $\mathrm{h}$ & $\mathrm{i}$ \\
\hline Employees & 1 & 1 & 1 & 1 & 1 & 1 & 1 & 1 & 1 \\
\hline Income & 1 & 1 & 1 & 1 & 1 & 1 & 1 & 1 & 1 \\
\hline Outcome & 1 & 1 & 1 & 1 & 1 & 1 & 1 & 1 & 1 \\
\hline $\begin{array}{l}\text { Employees } \\
\text { Salary }\end{array}$ & 1 & 1 & 1 & 1 & 1 & 1 & 1 & 1 & 1 \\
\hline $\begin{array}{l}\text { Overtime } \\
\text { cost }\end{array}$ & 1 & 1 & 1 & 1 & 1 & 1 & 1 & 1 & 1 \\
\hline Profit & 1 & 1 & 1 & 1 & 1 & 1 & 1 & 1 & 1 \\
\hline $\begin{array}{l}\text { Market } \\
\text { Capacity }\end{array}$ & 1 & 1 & 1 & 1 & 1 & 1 & 1 & 1 & 1 \\
\hline $\begin{array}{l}\text { Market } \\
\text { traders }\end{array}$ & 1 & 1 & 1 & 1 & 1 & 1 & 1 & 1 & 1 \\
\hline $\begin{array}{l}\text { Market } \\
\text { traders }>3 \\
\text { vears }\end{array}$ & 1 & 1 & 1 & 1 & 1 & 1 & 1 & 1 & 1 \\
\hline
\end{tabular}


Table 5. Slack analysis of output input variables against DMU

\begin{tabular}{lccc}
\hline & DMU & UPTD A & UPTD B \\
\hline & Score & 1 & 1 \\
& Rank & 1 & 1 \\
Slack & Employees & 0 & 0 \\
Slack & Income & 0 & 0 \\
Slack & outcome & 0 & 0 \\
Slack & Employees Salary & 0 & 0 \\
Slack & Overtime cost & 0 & 0 \\
Slack & Profit & 0 & 0 \\
Slack & Market capacity & 0 & 0 \\
Slack & Traders & 0 & 0 \\
Slack & Traders $>3$ years & 0 & 0 \\
\hline
\end{tabular}

The results of the analysis of input and output variable data result in a return to scale model BCC constant category. This category means that the data analyzed has an efficiency score of 1 and includes a constant retrun to scale. The next data processing is the statistics of the variables analyzed. The maximum value is owned by UPTD A while the minimum value is owned by UPTD B and the average value obtained from the total results of UPTD $\mathrm{A}$ and $\mathrm{B}$ are divided into two in each section. Standard deviation (SD) is a heterogeneous reference of a data element.

The next data processing is the statistics of the variables analyzed. The maximum value is owned by UPTD A while the minimum value is owned by UPTD B and the average value obtained from the total results of UPTD $\mathrm{A}$ and $\mathrm{B}$ are divided into two in each section. Standard deviation (SD) is a heterogeneous reference of a data element. The results of the standard deviation analysis stated that the data has heterogeneous levels as evidenced by the difference between SD and the average result has a considerable amount. The correlation of each input and output variable has the same value i.e. one. This correlation indicates that the output input variable has a positive correlation which means that the variable analyzed has a positive and directly proportional relationship. The last analysis is Slack which occurs on output input variables with DMU having a result of 0 indicating no slack occurrence in data analysis. Slack is a condition where DMU experiences weaknesses or deficiencies when compared to other DMU so it needs to be added other inputs and outputs. The research analysis object of UPTD $A$ and UPTD B has a balanced input output.

\section{CONCLUSION}

Based on the results and discussion explained above, thus it can be concluded that a) two UPTDs have an efficiency score of 1 meaning that two UPTDs have a balanced efficiency in their management. The correlation between input and output variables has a value of 1 which means a positive correlation that indicates there is a relationship between input and output variables that are positf and directly proportional. Input and output variables indicate no slack occurrence which means the variable has a balanced output input. 2) Differences in the management of UPTD Class A and Class B UPTD on the development of traditional markets in Salatiga City still make the development of traditional markets become in harmony with each other. 3) Market revitalization managed by UPTD A has developed market criteria and market management has a duty to maintain the control of the market environment. Revitalization of the market managed by UPTD B is a newly built market or revived market to be able to increase public interest in the market. Furthermore, it can be suggested that 1) the results that have been achieved by UPTD to be maintained and improved in the management of traditional markets in the market of Salatiga City. Efficiency and correlation that have been analyzed prove the achievement of both UPTD is good so that it can be maintained again and maximized performance. 2) Management differences as a result of the different challenges faced by both managers. Differences in management lead to increased innovation - innovations that have been used by managers in improving comfort, safety, and cleanliness are good enough but still need cooperation with traders from traditional markets to be able to maximize targets. 3) The 
grouping of traditional markets into two UPTD has been referring to the Salatiga City Trust so that the advice that can be given is to improve the performance of traditional markets in Salatiga City so as to maintain the performance of the Salatiga City Trade Office to manage the traditional market in Salatiga City. Defences that can be made include updating facilities to building markets, reviewing markets to be revived, and evaluating market performance on a regular basis.

\section{REFERENCES}

Abbott, M., \& Doucouliagos, H. (2004). Research Output of Australian universities. Education Economics, 12(3), 251-265. https:// doi.org/10.1080/0964529042000258608

Broekel, T., Rogge, N., \& Brenner, T. (2018). The Innovation Efficiency of German Regions A Shared-Input DEA Approach. Review of Regional Research, 38(1), 77-109. https:// doi.org/10.1007/s10037-017-0112-0

Cadillah, E. (2011). Eksistensi Pasar Tradisional. Yogyakarta: Balai Pelestarian Sejarah dan Nilai Tradisional.

Caginalp, C., \& Caginalp, G. (2019). Stochastic Asset Price Dynamics and Volatility Using a Symmetric Supply and Demand Price Equation. Physica A: Statistical Mechanics and Its Applications, 523, 807-824. https:// doi.org/10.1016/j.physa.2019.02.049

Castelló Taliani, E., Giralt Escobar, S., \& Silva Da Rosa, F. (2017). Environmental disclosure and economic efficiency: A correlational evaluation of Spanish ports authorities. Intangible Capital, 13(4), $745 . \quad \mathrm{https}: / /$ doi.org/10.3926/ic.937

Creswell, J. W. (2003). Research Design: Qualitative, Quantitative, and Mixed Methods Approaches. California: Sage Publications.

Dinas Perdagangan. (2021). Data Output dan Input. Salatiga.

Dixon, T. (2007). The Property Development Industry and Sustainable Urban Brownfield Regeneration in England: An Analysis of Case Studies in Thames Gateway and Greater Manchester. Urban Studies, 44(12), 2379-2400. doi.org/10.1080/00420980701540887

Fatimah, S., \& Mahmudah, U. (2017). Two-Stage Data Envelopment Analysis (DEA) for Measuring the Efficiency of Elementary Schools in Indonesia. International Journal of Environmental and Science Education, 12 (8), 1971-1987. Retrieved from http:// www.ijese.net/makale/1955.html

Ferricha, D., \& Fauzan. (2020). How The Policy And Empowerment Of Traditional Markets In Indonesia? International Journal of
Scientific \& Technology Research, 9(4), 3649-3652. Retrieved from http:// digilib.iain-jember.ac.id/id/eprint/726

Giantari, I. G. A. K., Surya, I. B. K., Yasa, N. N. K., \& Yasa, I. B. A. (2018). Development and Revitalization Strategies for Traditional Markets in Bali. International Journal of Social Economics, 45(7), 1058-1070. https://doi.org/10.1108/IJSE-09-2017-0414

Kiss, E. (2007). The Evolution of Industrial Areas in Budapest After 1989. In The PostSocialist City (pp. 147-170). https:// doi.org/10.1007/978-1-4020-6053-3 8

Lampe, H. W., \& Hilgers, D. (2015). Trajectories of Efficiency Measurement: A Bibliometric Analysis of DEA and SFA. European Journal of Operational Research, 240(1), 1$21 . \quad$ https://doi.org/10.1016/ j.ejor.2014.04.041

Major, M. D., \& Tannous, H. O. (2020). Form and Function in Two Traditional Markets of the Middle East: Souq Mutrah and Souq Waqif. Sustainability, 12(17), $7154 . \quad$ https:// doi.org/10.3390/su12177154

Martinez-Budria, E., Diaz-Armas, R., NavarroIbanez, M., \& Ravelo-Mesa, T. (1999). A Study of the Efficiency of Spanish Port Authorities Using Data Envelopment Analysis. International Journal of Transport Economics, 26(2), 237-253. Retrieved from https://www.jstor.org/stable/42747746

Milliken, O., Devlin, R. A., Barham, V., Hogg, W., Dahrouge, S., \& Russell, G. (2011). Comparative Efficiency Assessment of Primary Care Service Delivery Models Using Data Envelopment Analysis. Canadian Public Policy, 37(1), 85-109. https://doi.org/10.1353/cpp.2011.0009

Murbarani, T. D. (2018). Analisis efisiensi teknis terhadap revitalisasi pasar tradisional di kota surakarta. Retrieved from http:// eprints.ums.ac.id/63364/

Nandy, A., \& Singh, P. K. (2020). Farm Efficiency Estimation Using a Hybrid Approach of Machine-Learning and Data Envelopment Analysis: Evidence from Rural Eastern India. Journal of Cleaner Production, 267, $122106 . \quad$ https://doi.org/10.1016/ j.jclepro.2020.122106

Niswati, Z. A. I. (2014). Analisis Efisiensi Kinerja Menggunakan Model Data Envelopment Analysis (Dea) Pada Pt Xyz. Universitas Indraprasta PGRI.

Pan, M., \& Song, H. (2017). Transformation and Upgrading of Old Industrial Zones on Collective Land: Empirical Study on Revitalization in Nanshan. Habitat International, $65, \quad 1-12 . \quad \mathrm{https}: / /$ doi.org/10.1016/j.habitatint.2017.04.014

Pemerintah Kota salatiga. (2018). Peraturan Walikota (PERWALI) tentang Pembentukan Unit Pelaksana Teknis Daerah Pasar Pada Dinas Perdagangan (p. 6). p. 6. Salatiga. 
Putra, R. D. D., \& Rudito, B. (2015). Planning Community Development Program of Limbangan Traditional Market Revitalization with Social Mapping. Procedia - Social and Behavioral Sciences, 169, 143-150. https://doi.org/10.1016/ j.sbspro.2015.01.296

Ren, L., Shih, L., \& McKercher, B. (2014). Revitalization of industrial buildings into hotels: Anatomy of a policy failure. International Journal of Hospitality Management, 42, 32-38. https:// doi.org/10.1016/j.ijhm.2014.06.007

Sepulveda, C. F. (2020). Explaining the demand and supply model with the cost-benefit rule. International Review of Economics Education, 35, $100194 . \quad$ https:// doi.org/10.1016/j.iree.2020.100194

Sitohang, M. H., Marpaung, B. O. ., \& Lubis, A. M. (2020). Study of Cemara Traditional Market development in Medan Timur District. IOP Conference Series: Earth and Environmental Science, 452, 012147. https://doi.org/10.1088/17551315/452/1/012147

Wahyudi, D., Hasanah, E., Ummi, E., Gravitiani, Syamsiro, M., Lantarsih, R., \& Prasetyanto, H. (2019). Green Village for a Sustainable Tourism on Srimulyo Village, Piyungan, Bantul. The 1 Internasional Forum Business and Economy (IFBE) 2019, 79-85. Banjarmasin: Fakultas Ekonomi dan Bisnis Universitas Lambung Mangkurat.

Widiyana, S. S., \& Indiyanto, R. (2017). Analisa Pengukuran Efisiensi Dengan Metode Data Envelopment Analysis (Dea) Di Heaven Store Surabaya Barat. PROZIMA (Productivity, Optimization and Manufacturing System Engineering), 1(1), 44. https://doi.org/10.21070/

prozima.v1i1.705 